\title{
STATE PLANNING OF RESEARCH
}

The Contempt of Freedom:

the Russian Experiment and After. By M. Polanyi. Pp. $\mathrm{ix}+116$. (London: Watts and Co., Ltd., 1940.) 5s. net.

IMPATIENCE at the delay in attaining the higher level of human welfare which science has made possible has led to a movement for the organization of research under State control and its more direct application to industrial and economic ends. Prof. Polanyi subjects this movement to a profound and penetrating criticism. He concludes that it would tend to lead to the loss of freedom of thought and freedom of expression of views contrary to authority and shows that this is, indeed, what happened in the U.S.S.R. with the vertical organization of research to State ends and under State control. The results of State planning of research are as disappointing as the results of the economic and social planning which he also discusses.

This book contains a message and a warning for scientific workers enamoured of planning. The first objective of planning should be the maintenance of freedom of thought and expression where it still exists, and its return where it has been lost. This freedom is absolutely essential for original research. It is also the first essential for human progress. People in authority, even in democratic countries, may resent the exercise of this freedom by those under them. It can easily be lost unless it is continually defended and fought for. We are not so many generations removed from the time when expression of views different from those held by the Church or the State was followed by persecution and even death. In most of Europe to-day the torch of liberty has been extinguished. Truth is being forcibly suppressed, and public opinion moulded for State purposes by open and hidden forms of propaganda, which prevail because those who know the truth are rendered dumb.

Even in democratic countries, there is a danger of the voice of reason being drowned in the flow of political propaganda, and the organization of science by the State may deprive scientific men of the full liberty of expression and freedom to criticize the policy of those in authority. The only authority scientific workers acknowledge is the truth. In these dark days through which civilization is passing, probably the most valuable service which men of science can give to humanity is the defence of freedom, described by Milton as "the liberty to know, to utter, to argue freely according to conscience which is above all liberties".

\section{PHOTOSYNTHESIS BY PLANTS AND BY CHEMISTS}

\section{Photosynthesis}

By Prof. E. C. C. Baly. Pp. vii +248 . (London : Methuen and Co., Ltd., 1940.) 15s, net.

Trwh WENTY years ago Prof. Baly first became interested in the debate whether formaldehyde could be photosynthesized artificially in a solution of carbon dioxide. Since then he has been continuously engaged in restating, retesting and reconsidering the problem. Now, in his retirement, he fights his battles over again within the covers of this book, recording successes which advance far beyond the first objective. Not only has formaldehyde been produced, but also glucose ; a starch; the bases imidazole, pyridine and piperidine; coniine and two other alkaloids; $\alpha$-amino-acids, including histidine; and a protein the molecular weight of which is given as $221 \cdot 4$. Very few of these substances have ever been photosynthesized in any laboratory other than that of Prof. Baly.
The path leading to these results has not been facile; on the contrary, the conditions of success have often proved stringent, and apparent successes, even though not illusory, have not always proved to be quite what they at first appeared. As an example the synthesis of mixed carbohydrates with the assistance of nickel carbonate may be mentioned. An independent attempt at repetition failed completely, to the emphatically expressed surprise of the author, who had believed the results to be reproducible and their confirmation a simple matter. It proved in the upshot to be far from such, and neither Prof. Baly nor anyone else has yet succeeded in repeating the results originally obtained in 1928 . The margin between success and failure is believed to have been the chance use of a glass of abnormally low solubility which it has not been possible to get again.

With so much hanging upon so slender a thread, 